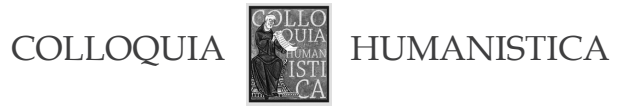

Katarzyna Taczyńska

Instytut Filologii Słowiańskiej

Uniwersytet Mikołaja Kopernika

Toruń

\title{
Prace Komisji Środkowoeuropejskiej Prezentacja cyklu
}

zereg transformacji dokonujących się na początku lat 90. w krajach $\checkmark$ postkomunistycznych Europy Środkowo-Wschodniej spowodował konieczność wydobycia nowych aspektów i pogłębienia badań nad różnymi zagadnieniami związanymi z kulturami tego obszaru. Drobiazgowe, wnikliwe studia nad problemami Europy Środkowej stały się jednym z prymarnych zadań realizowanych przez powstałą w 1991 r. z inicjatywy prof. Henryka Batowskiego Komisję Środkowoeuropejską przy Wydziale Historyczno-Filozoficznym Polskiej Akademii Umiejętności. Pokłosiem działalności Komisji są wydawane od 1993 r. w rocznych odstępach tomy pod wspólnym tytułem - „Prace Komisji Środkowoeuropejskiej”. Powołanie Komisji i wydawanie periodyku wypełniło w sposób znaczący lukę w badaniach nad historyczną, filologiczną i kulturową problematyką narodów wchodzących w zakres pojęcia Europy Środkowej, czyli - jak podają redaktorzy tomu narodów zamieszkujących tereny „między Bałtykiem a Adriatykiem, Łabą, Niemnem, Bugiem i Dunajem - po obu stronach tej wielkiej rzeki, w jej środkowym brzegu"'.

Komisja w swoich szeregach skupia badaczy-specjalistów różnych dyscyplin naukowych, dzięki którym artykuły zawarte w poszczególnych tomach obejmują szeroki wachlarz tematyczny i mają charakter interdyscyplinarny. Naukowcy analizują zagadnienia, korzystając z różnych metodologii. Problemy poruszane w tekstach po wielokroć wchodziły w skład większych projektów badawczych, których poszczególne etapy są prezentowane i dyskutowane na spotkaniach naukowych Komisji. Autorami studiów są pro-

Wstęp do „Prace Komisji Środkowoeuropejskiej” 1993, t. 1, red. H. Batowski, J. Machnik, s. 7. 
fesorowie i młodsi pracownicy naukowi z Polski oraz z zagranicy. Ścisła i stała współpraca między naukowcami różnych krajów zaowocowała regularną wymianą informacji na temat aktualnych osiągnięć wielu prestiżowych ośrodków badawczych. Międzynarodowa formuła prezentowanych artykułów zdecydowała również o tym, by artykułom towarzyszyły streszczenia w języku angielskim.

Tematyka studiów podjęta w periodyku Komisji oczywiście nie ogranicza się do kwestii bezpośrednio związanych z obszarem zamieszkanym przez środkowoeuropejskie narodowości, ale odwołuje się również do ich relacji z terenami sąsiednimi, z uwzględnieniem geopolitycznych zmian na przestrzeni wieków. Tym samym badacze skupiają się na odległej częstokroć przeszłości i rozważają wielorakie kwestie z perspektywy współczesnej.

Warte odnotowania jest, iż redaktorzy kolejnych tomów starają się, by przygotowywany przez nich zbiór zawierał także artykuły bezpośrednio zorientowane na najaktualniejsze przemiany współczesnej Europy Środkowej. Stąd na przykład na łamach „Prac” można prześledzić systematycznie pojawiające się studia zogniskowane wokół problemów Bałkanów, w tym przede wszystkim wokół losów byłej Jugosławii. Różnorodność i mnogość sposobów przyglądania się poszczególnym kwestiom zasługuje na osobną adnotację. W odniesieniu do Bałkanów odnajdujemy bowiem m.in. artykuł Ireny Stawowy-Kawki podejmujący temat odrodzenia narodowego Narodowe i państwowe aspiracje Macedończyków (1993, t. 1), pracę Henryka Batowskiego omawiającą palące problemy terenów Bośni Problem bośniac$k i$ - podstawy historyczne (t. 2), studium Marka Waldenberga analizujące i komentujące najnowsze działania na Bałkanach Zmiany na bałkańskiej szachownicy politycznej $(1994$, t. 2), natomiast jeszcze inny punkt widzenia spotkać można w tekście Erharda Cziomera, który przygląda się Bałkanom przez pryzmat dyskursu zachodniego - Świat zachodni wobec Bałkanów, ze szczególnym uwzględnieniem kryzysu jugosłowiańskiego lat 90. (1994, t. 2). Ponadto w artykułach rozpatruje się kwestie związane ze stosunkami historycznymi, politycznymi i społecznymi w regionach mieszanych pod względem etnicznym, kulturowym i religijnym, przykładem są teksty Ireny Stawowy-Kawki, Problem albański w Republice Macedonii (1996, t. 4), Aleksandry Stankowicz, Ivo Andrić a problemy narodowościowe w byłej Jugosławii (1999, t. 6), Mirelli Korzeniewskiej-Wiszniewskiej, Kosowo w serbskich źródłach historycznych, wypowiedziach polityków i opiniach prasowych $(2009$, t. 17).

$\mathrm{Na}$ specjalną uwagę zasługuje również fakt, iż wśród tomów zróżnicowanych pod względem problematyki naukowej znajdują się również cykle monotematyczne, jak t. 8 z 2000 r. zatytułowany Metropolie Europy Środkowo-Wschodniej wXViXVI wieku. Tom ten powstał jako rezultat sesji naukowej zorganizowanej przez Komisję w Krakowie w 1998 r., na której wygłoszono 
referaty przygotowane przez pracowników Centrum Badań nad Historią i Kulturą Europy Środkowo-Wschodniej w Lipsku. Naukowcy z lipskiego Centrum zaprezentowali podczas sesji wyniki badań opracowywanych w ramach projektu Metropolie Europy Środkowo-Wschodniej w XV-XVII wieku.

Bez najmniejszych wątpliwości „Prace Komisji Środkowoeuropejskiej” należy ocenić jako wartościowe źródło wiedzy na temat regionu, który do momentu powołania Komisji traktowany był w nauce polskiej peryferyjnie. Podjęta więc przez autorów próba dowartościowania regionu i upomnienia się o należne mu miejsce wśród dotychczasowych badań jest ze wszech miar działaniem cennym. Niewątpliwie również kolejne tomy Komisji wpływają bezpośrednio na popularyzację niezwykle ważnych zagadnień związanych z tym obszarem Europy. 